\title{
Migratory rhythms of drifting juvenile molluscs in tidal waters of the Wadden Sea*
}

\author{
Werner Armonies
}

Biologische Anstalt Helgoland, Wattenmeerstation Sylt, W-2282 List, Germany

\begin{abstract}
After initial spatfall, some species of bivalves and juvenile mud snails may re-enter the water column and thus undergo secondary dispersal. Using continuous plankton net records of the number of drifting organisms over a period of 4 mo in summer 1991, rhythms of migratory activity were analysed on a tidal flat area near the Island of Sylt, eastern North Sea. All abundant species showed a clear diurnal pattern. The mud snail Hydrobia ulvae was more abundant in the water column during daytime than in the dark, while the reverse was true for the bivalves observed. In addition, cockles Cerastoderma edule and razor clams Ensis directus displayed a semilunar rhythm of drifting activity: and in clams Macoma balthica there was a $10 \mathrm{~d}$ periodicity not closely linked to lunar phases. In most species, the quantitative effect of these longer periodicities was stronger than that of the diurnal component. The pattern of migratory activity, resulting from these diurnal and lunar rhythms together with a seasonal component, was distorted by weather conditions in a species-specific way. As a consequence, records of drifting young molluscs may be severely biased unless these rhythms of migratory activity are taken into account.
\end{abstract}

\section{INTRODUCTION}

Juveniles of many macrobenthic infaunal species have been recorded in the water column (see review by Butman 1987). In some cases the drifting specimens seem to be lifted off the sediment by strong currents or waves, while other species occur too frequently and regularly to assume passive displacement as the sole cause of their water column entry (e.g. Williams \& Porter 1971). This is particularly true for some mollusc species, which are known to build an assisting device for drifting in the water column. In marine bivalves, thin mucus threads many times the length of the animal increase the hydrodynamic drag on the organisms and enable them to be lifted and transported in the water column by currents (Sigurdsson et al. 1976, Yankson 1986, Beukema \& de Vlas 1989). In larger specimens buoyancy may be enhanced by an extreme protrusion and swelling of the foot (Sörlin 1988). Some species such as Ensis directus may even swim actively (Williams \& Porter 1971 and references therein). Gastropods such as Hydrobia ulvae may float at the water surface (Little \& Nix 1976).

\footnotetext{
- Contribution No. 29 of the project Ecosystem Research Wadden Sea'
}

Both thread drifting and floating may result in longdistance dispersal and may enable the specimens to settle, at a later time and with a larger size, away from the area occupied by the recently metamorphosed larvae. De Vlas (1973) caught high numbers of threaddrifting clams Macoma balthica in tidal channels of the western Wadden Sea during winter and early spring. Again in winter, Beukema \& de Vlas (1989) found a net export of clams from the Wadden Sea towards the North Sea. They concluded that the North Sea population of $M$. balthica may depend on immigration of larger juveniles from the Wadden Sea, because there is only a low rate of successful primary settlement in the subtidal. Thus, by secondary dispersal a species may enlarge its distributional range.

In the same species there is also evidence for a net transport of thread-drifting juveniles from lower to higher intertidal sites (Günther 1991, and author's own unpubl. obs.). The latter studies dealt with the migration of smaller size classes in summer and indicate that thread-drifting in Macoma balthica is not restricted to medium-sized specimens in winter, as was concluded from laboratory experiments (Sörlin 1988).

This study focuses on the migratory activity rhythms of young bivalves and mud snails in the northern Wadden Sea during summer. While it was initially planned 
to study the effects of drifting by simultaneous sampling of the water column and the sediment, the number of drifters in the water column were to vary considerably over narrow time scales, and there seemed to be a distinct activity pattern in every species. Thus it was decided to investigate the temporal abundance pattern of drifters in the water column first. Studies on the consequences of these migrations are in progress.

\section{MATERIALS AND METHODS}

Recording drifting benthos. A preliminary study in 1990 tested various designs of plankton nets and traps for their efficiency in collecting drifting benthos from the water column. The tests included long $(1 \mathrm{~m})$ and short $(0.5 \mathrm{~m})$ nets, with or without an inner cone, and with or without a terminal collecting device. Two designs were tested simultaneously in the field over at least 10 tidal cycles (with the net contents examined at every low tide). The better design in each run (Wilcoxon's matched pairs signed rank statistic) was then tested against the next modification. There was no single design that was equally fit for all of the various taxa. Long nets with one or several inner cones should be used for the better swimmers such as amphipods or cumaceans. The more delicate species are better conserved in nets with a terminal collecting device, which, however, reduces the filtering efficiency by its higher resistance to currents.

For molluscs the simplest design turned out to work best. It consisted of a plankton net $55 \mathrm{~cm}$ long and $21 \mathrm{~cm}$ in diameter. A $5 \mathrm{~cm}$ long piece of plastic tube (inner diameter $20 \mathrm{~cm}$, outer diameter $21 \mathrm{~cm}$ ) kept the mouth of the net open. The net was sewn up at one end, thus forming a simple bag (Fig. 1A). Both 0.5 and 1.0 mm meshes were used for the net; the latter yielded more reliable results in periods of high phytoplankton density.

A pair of nets (one for each mesh size) were screwed horizontally to a common frame (Fig. 1B). This frame consisted of a central piece of plastic pipe $(20 \mathrm{~cm}$ long) with 2 lateral wooden carriers for the nets. The central plastic pipe allowed the whole frame with the nets to rotate freely around the vertical anchor pipe $(2 \mathrm{~m}$ long, stainless steel; Fig. 1C). In this way the nets could adjust themselves according to the direction of the tidal currents. The vertical distance of the nets from the sediment was controlled by a set of plastic discs fixed to the anchor pipe (Fig. 1C). During this study the distance of the lower disc from the sediment was always $15 \mathrm{~cm}$ (corresponding to a distance of $25 \mathrm{~cm}$ from the sediment to the center of the net openings). For vertically stratified sampling, several frames may be fixed to the same anchor pipe.

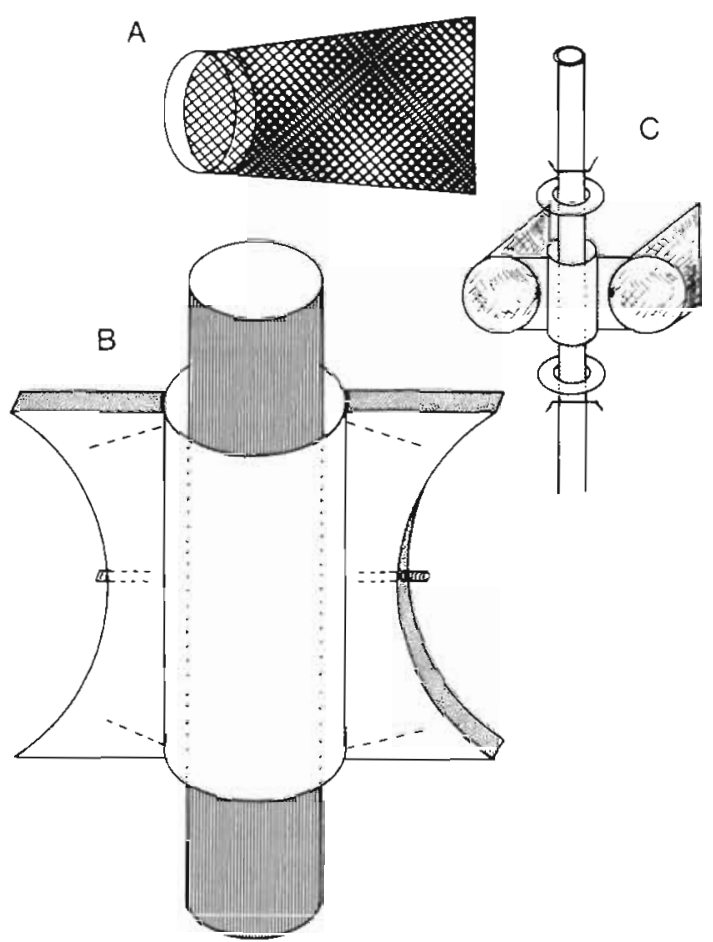

Fig. 1. Horizontal plankton nets for collecting drifting benthos at a fixed shallow water site. (A) Single net with a reinforced opening; (B) frame for one net on either side with central anchor pipe; (C) anchor pipe with the frame and upper and lower discs keeping the nets at a fixed distance from the sediment. The discs rest on a piece of strong wire driven through holes bored in the vertical anchor pipe. Dashed lines in (B) indicate the position of hidden screws. Diameter of the nets is $20 \mathrm{~cm}$

Study site and sampling. Drifting benthos was recorded in the southern Oddewatt, which is the outer part of the Königshafen wadden area near the Island of Sylt (North Sea; Fig. 2). The sediment in the Oddewatt consists mainly of medium to fine sand in the central part, muddy sand in the upper intertidal, and fine sand in the lower intertidal and shallow subtidal. Ticles are semidiurnal, with an average range of $1.8 \mathrm{~m}$ in the area and $1.5 \mathrm{~m}$ at the site where drifters were collected (i.e. $0.3 \mathrm{~m}$ above mean low tide level). A general description of the area is given in Reise (1985). Abundant molluscs in the Oddewatt area are the mud snail Hydrobia ulvae, Littorina spp., the clam Macoma balthica, cockles Cerastoderma edule, sandgapers Mya arenaria, razor clams Ensis directus, and mussels Mytilus edulis.

Between 6 June and 3 October 1991, amples were collected by changing the nets during low tide. This was done every low tide between 04:00 and 23:00 h. During low tides outside this range the nets were left unchanged for 2 tidal cycles. In the laboratory, the nets were cleared and the trapped specimens sorted to species level and counted. Specimens of Macoma balthica and Cerastoderma edule were measured to the 


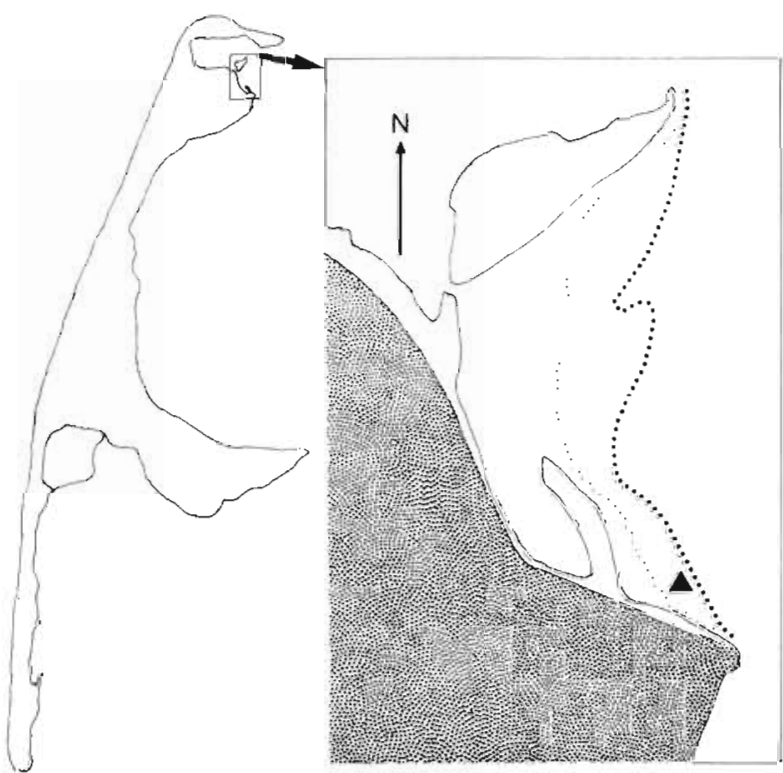

Fig. 2. Study site in the Oddewatt (inset) near the Island of Sylt. Heavy dotted line indicates mean low tide level, light dotted line mean tide level. Shaded areas are higher than mean high tide level; darkest shading: diked land; arrowhead: sampling site. Total height of inset represents $2.5 \mathrm{~km}$; total intertidal area is $0.75 \mathrm{~km}^{2}$

nearest $0.5 \mathrm{~mm}$. Hydrobia ulvae was sorted into 2 size classes, viz. $<2$ or $>2 \mathrm{~mm}$ length. No measurements were made when the number of specimens in a single net exceeded 500

Statistical analyses. The preliminary study revealed that abundance of mollusc drifters in the water column is a function of a seasonal component that is modulated by a 'lunar' and a diurnal component. The resulting patterns are varied by irregular exogenous factors on narrow time scales, such as weather conditions.

The diurnal component of migratory activity may be estimated directly from the raw data by comparing the numbers per species caught during consecutive tides (Wilcoxon's matched pairs signed rank statistic, in Sachs 1984). This was done for all sampling dates with 2 separate measurements per day, i.e. excluding measurements over more than a single tidal cycle. For further analyses the diurnal component was excluded by pooling the nocturnal and daytime catches of consecutive tides, thus obtaining a measure of migratory activity per 2 tidal cycles. This procedure worked well for all species but Hydrobia ulvae (see below).

Results of a preliminary analysis showed that the amplitude of the lunar activity component depends on the seasonal component. Both should therefore be combined in a multiplicative model. However, since an additive model is more convenient mathematically, the raw data were $\log (x+1)$ transformed prior to further analyses.
Classical methods of time-series analysis (all from Hartung 1989) were used to estimate the lunar periodicity. The series of log-transformed numbers per species per 2 tidal cycles was first smoothed by a simple (unweighted) moving average. Smoothing reduces the short-term variance which is assumed to be mainly due to weather conditions (see below). What results from smoothing is a generalized series mainly representing a combination of seasonal and lunar components. Next, the time series was detrended by calculating the first differences. This eliminated the seasonal component and thus revealed the lunar periodicity, which was further generalized by its autocorrelation function. The seasonal component was estimated by polynomial regression.

The differences between the original and the smoothed (simple 5-term moving average) time series represented an estimate of the short-term irregular variations in the number of drifters. From a preliminary study it was suggested that weather, mainly wind, could be a significant cause of these short-term variations. Multiple regression analyses with stepwise variable selection was used to test the impact of wind on these differences. Variables with $F>4$ (overall $F$-test) were kept in the model and those with $F<4$ were removed. Significance of the selected parameters was tested by a partial F-test (Fahrmeir et al. 1989). Wind data used were wind velocity and wind direction for each of the following intervals: daytime flood tide, daytime ebb tide and both combined (daytime tide); nocturnal flood tide, nocturnal ebb tide, and both combined (nocturnal tide); ebb tides and flood tides (averages of the respective daytime and nocturnal measurements); and overall averages of 2 tidal cycles. All wind data were obtained from the Meteorological Station in List (about $2 \mathrm{~km}$ from the sampled wadden area).

The analysis of weather-induced changes in migratory activity only attempted to test for the significance of wind. Results obtained by such an approach may be only of heuristic value, for 5 reasons: (1) Only wind data are used. For some species such as Hydrobia ulvae variations in light intensity, caused by clouds, may be equally important (Newell 1962). Since there is a diurnal rhythm in migratory activity in all abundant species (see below), light intensity may even be generally important. (2) Wind presumably exerts its influence only in an indirect way, by changing the tidal currents or by causing mechanical damage to the mucus threads of bivalves in the case of wind-induced waves. (3) Neither wind direction (measured to the nearest $10^{\circ}$ ) nor wind velocity (in knots) data were transformed prior to analysis. A sine transformation of wind directions and a log transformation of wind velocity data might have been more meaningful. In addition, the 
preliminary study indicated that wind effects are not linearly correlated with the numbers of drifters in the water column. Instead, slight to moderate wind velocity increases the numbers of drifters caught by the nets because they then filter more water, while drifting ceases during strong wind. (4) Since wind acts on the hydrographic regime, the most effective wind direction depends on the topography of the studied area and therefore cannot be generalized. (5) Besides short-term weather events, other factors such as salinity, water temperature, and oxygen should also be mentioned. In part, these factors may already be hidden in the seasonal component of migratory activity.

\section{RESULTS}

\section{Size distribution of drifting molluscs}

Numbers of floating mud snails Hydrobia ulvae were low in June, when individuals $>2 \mathrm{~mm}$ shell length dominated the collection of drifting individuals. In July to September, abundance was considerably higher and drifting mud snails were predominantly juveniles $<2$ $\mathrm{mm}$ (Fig. 3).

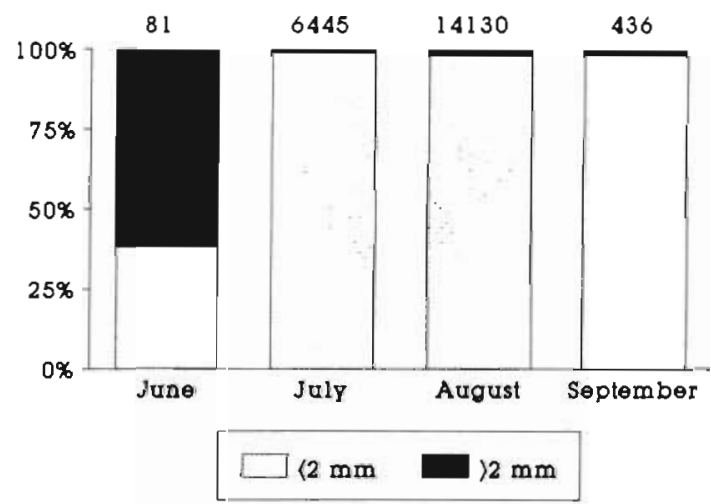

Fig. 3. Hydrobia ulvae. Size distribution of floating individuals in summer 1991. Numbers above the columns indicate the total number of individuals

Juvenile clams Macoma balthica were 0.7 to $4 \mathrm{~mm}$ long with an average size of $1.54 \mathrm{~mm}$. With the exception of the smallest size class, the 0.5 and $1.0 \mathrm{~mm}$ nets caught the same numbers of individuals per size class $\left(x^{2}\right.$ test, $\left.x^{2}=3.330, \mathrm{df}=4, \mathrm{p} \approx 0.5\right)$. The average size per $4 \mathrm{~d}$ sampling interval varied over time (Fig. 4 ) but there was no significant linear correlation with time (Spearman's rank correlation coefficient, $r_{5}=-0.062, n=24$ ) or with the number of specimens caught per sampling interval $\left(r_{s}=-0.051\right)$. The average size of specimens caught during day and night did not differ significantly (sign test, $\mathrm{p}>0.2$ ).

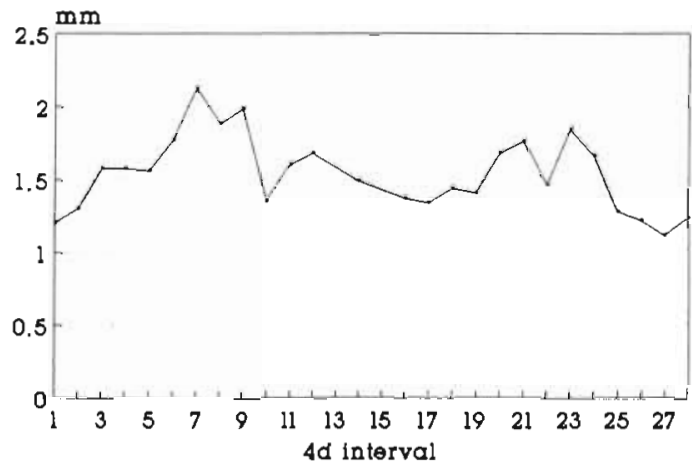

Fig. 4. Macoma balthica. Average size of drifting organisms per 4 d period, June to September 1991. Specimens caught during 8 consecutive tides were pooled to obtain a sufficient number of specimens for calculating average sizes from a scale divided into $0.5 \mathrm{~mm}$ intervals

Drifting cockles Cerastoderma edule were $1.26 \mathrm{~mm}$ long on average (range 0.5 to $3.5 \mathrm{~mm}$ ). Specimens were all smaller than $1 \mathrm{~mm}$ until the middle of June and the average length increased to $1.5 \mathrm{~mm}$ until the end of July (Fig. 5). Size theñ decreased âgainin, mainly due to a

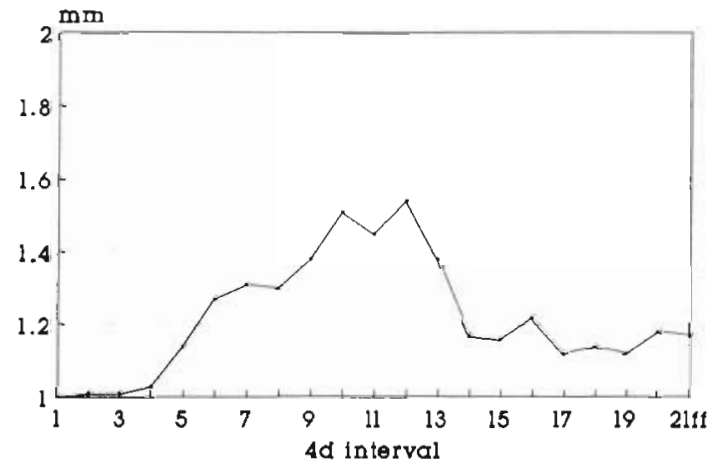

Fig. 5. Cerastoderma edule. Average size of drifting organisms per 4 d interval, June to August 1991 as in Fig. 4. Because of low abundance, specimens occurring after Interval 21 were added to that interval

lower percentage of the relatively large-sized organisms. Specimens caught during the day were slightly smaller $(1.26 \mathrm{~mm})$ on average than those caught at night $(1.31 \mathrm{~mm}$; sign test on the average size during consecutive tides, $\mathrm{p}<0.05$ ).

Razor clams Ensis directus were mostly 1 to $3 \mathrm{~mm}$ long, occasionally up to $5 \mathrm{~mm}$. Specimens $>3 \mathrm{~mm}$ only occurred during 2 distinctly separate intervals: (1) from the middle of June to the end of July, and (2) from the beginning of September onwards. Mytilus edulis, Venerupis pullastra, Mya arenaria and Montacuta spp. only occurred in low numbers. These specimens were mostly about $1 \mathrm{~mm}$ (0.5 to $1.5 \mathrm{~mm})$ long. Because of low abundances, the latter species are not further mentioned. 


\section{Diurnal rhythms}

A clear diurnal rhythm of drifting activity was seen in all 4 of the abundant species. Hydrobia ulvae was more active during daytime while Cerastoderma edule, Macoma balthica, and Ensis directus were all more abundant in the water column at night (Table 1).

Table 1 Diurnal differences in the abundance of drifting molluscs in the water column. $D: N$ is the ratio of the average abundance during daytime and nocturnal catches; $D: N(\log )$ is the same based on log-transformed data. Significance was determined according to Wilcoxon's matched pairs signed rank statistic, performed on the abundances during 2 consecutive tides

\begin{tabular}{|lrrl|}
\hline Species & $D: N$ & $D: N(\log )$ & $\mathrm{p}$ \\
\hline Cerastoderma edule & $1: 2.81$ & $1: 1.28$ & $<0.001$ \\
Macoma balthica & $1: 2.05$ & $1: 1.38$ & $<0.05$ \\
Ensis directus & $1: 7.31$ & $1: 2.19$ & $<0.001$ \\
Hydrobia ulvae & $2.55: 1$ & $1.23: 1$ & $<0.001$ \\
\hline
\end{tabular}

\section{Seasonal and 'lunar' components}

For the following analyses, the diurnal component of migratory activity was eliminated by pooling the numbers per species caught during 2 consecutive tidal cycles each.

Cerastoderma edule. The seasonal trend (as estimated by polynomial fitting) had a single peak, with highest abundance in the end of June and a fairly regular decline until September (Fig. 6B). From the original data (Fig. 6A) it seemed that a graph with a second peak at time index 70 (mid-August) was an alternative interpretation. The size distribution of drifting organisms, however, did not support the second assumption (see above). The lunar component showed a period of $15 \mathrm{~d}$ (Fig. 6C) and every peak in the smoothed abundance graph coincided with a spring tide (indicated by arrows in Fig. 6B). However, there was a single spring tide at time index 80 with no corresponding abundance peak (Fig. 6B). Autocorrelation of data with a $30 \mathrm{~d}$ lag was markedly higher than that with a $15 \mathrm{~d}$ lag (Fig. 6C). This is because there were 2 outstanding peaks of abundance at a $30 \mathrm{~d}$ intervals, both during spring tides after new moon.

Ensis directus. Seasonally, there were 2 periods of high abundance of juvenile razor clams in the water column (Fig. 7A, B). From the size of the drifting organisms it seems that these reflected 2 different reproductive periods, the first of which was partly outside the observational time window. The lunar component had a period of $14 \mathrm{~d}$ (Fig. 7C). Every peak in abundance corresponded with a spring tide and vice versa. The
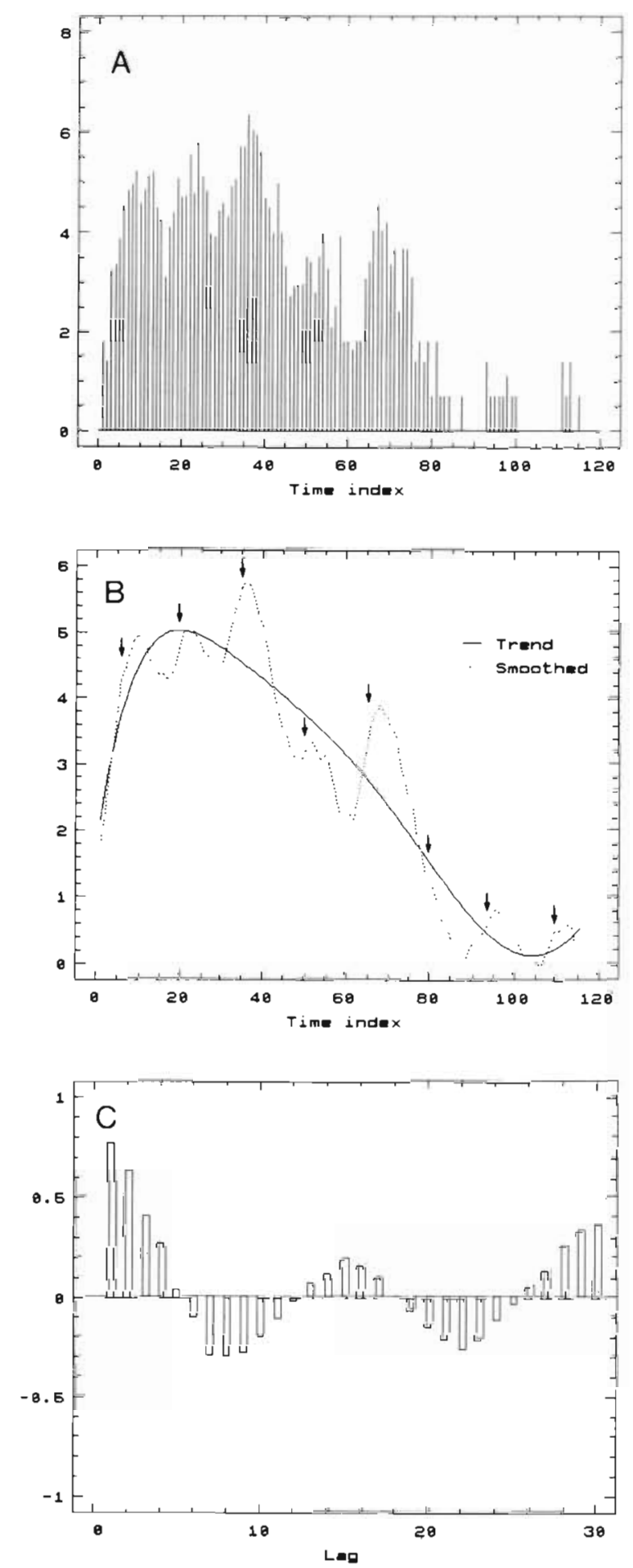

Fig. 6. Cerastoderma edule. (A) $\log (x+1)$ transformed raw data of total abundance of drifters per 2 tidal cycles; (B) smoothed abundance line and estimated polynomial trend (arrows indicate the timing of full and new moon); (C) autocorrelation function of detrended data, measuring the correlation (range +1.0 to -1.0 ) of abundances observed on a temporal distance (lag) of $1,2, \ldots, 30 \mathrm{~d}$. Time index (d): Day $1=7$ June 1991, Day $25=1$ July; Day $56=1$ August; Day $87=1$ September; Day $117=1$ October 

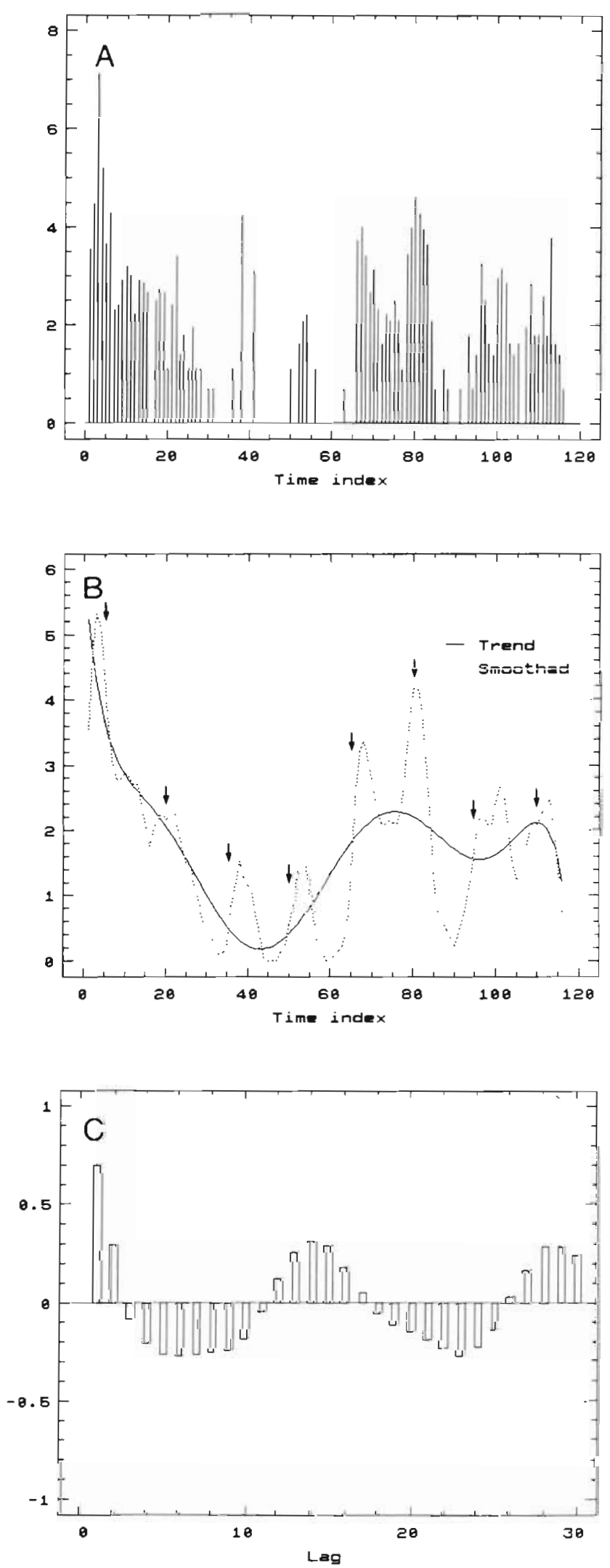

Fig. 7 As in Fig. 6 but for Ensis directus preference for the spring tide periods was more marked than in Cerastoderma edule, as is indicated by the relatively higher number of lags with a negative autocorrelation (Fig. 7C).

Macoma balthica. Abundance of drifting clams was the least regular among the abundant bivalves (Fig. 8A). The polynomial trend showed several peaks which were not mirrored in the size distribution of drifting organisms. Thus, multiple periods of reproductive activity resulting in several cohorts of drifting juveniles were not indicated. The multiple peaks were possibly caused by strong weather-induced variations (see below). Drifting showed a (presumably endogenous) rhythm with a period of $10 \mathrm{~d}$ (Fig. 8C). Therefore only about every third peak of abundance coincided with a spring tide. In 1991 these were the full moon spring tides, but during the preliminary study in 1990 these were the new moon spring tides.

Hydrobia ulvae. Apart from the diurnai rhythm, no other periodicity of floating activity could be found in mud snails. The low-amplitude modulation with a period of $1 \mathrm{wk}$ visible in Fig. 9 does not represent an extra enuogenous rhythnin but is a residual of the attempt to eliminate the diurnal component by pooling the numbers caught during 2 consecutive tides. This procedure worked well for the bivalves, which are predominantly active at night. Mud snails, however, are more active during daylight. Because the investigated area is situated in a boreal part of the world, summer nights are relatively short ( $<6 \mathrm{~h}$ in the middle of June) with long periods of dawn and dusk (about $1 \mathrm{~h}$ each). Hydrobia ulvae mainly occurs in the upper intertidal with a submersion time of $<6 \mathrm{~h}$. Therefore, in approximately weekly intervals darkness coincides with the period of low tide at these sites and both high tides of the day occur in daylight. Then, pooling 2 consecutive tides means pooling a nocturnal and a daytime high tide in one week, but pooling 2 high tides with daylight in the following week. Consequently, a $1 \mathrm{wk}$ variation of floating activity in $H$. ulvae is the result.

\section{Correlations with wind data}

Multiple regressions of wind data on estimates of irregular short-time changes of migratory activity revealed a species-specific pattern for the most important wind factors (Table 2). The strongest influence of wind occurred in Macoma balthica $\left(\mathrm{R}^{2}=0.301\right)$ and the original time series of abundance was the least regular in this species. The reverse was true for Cerastoderma edule and Ensis directus (see Figs, 6 to 9). Although all species showed a clear diurnal pattern of activity (Table 1), the selected variables do not exclusively relate to the period of highest migratory activity. 

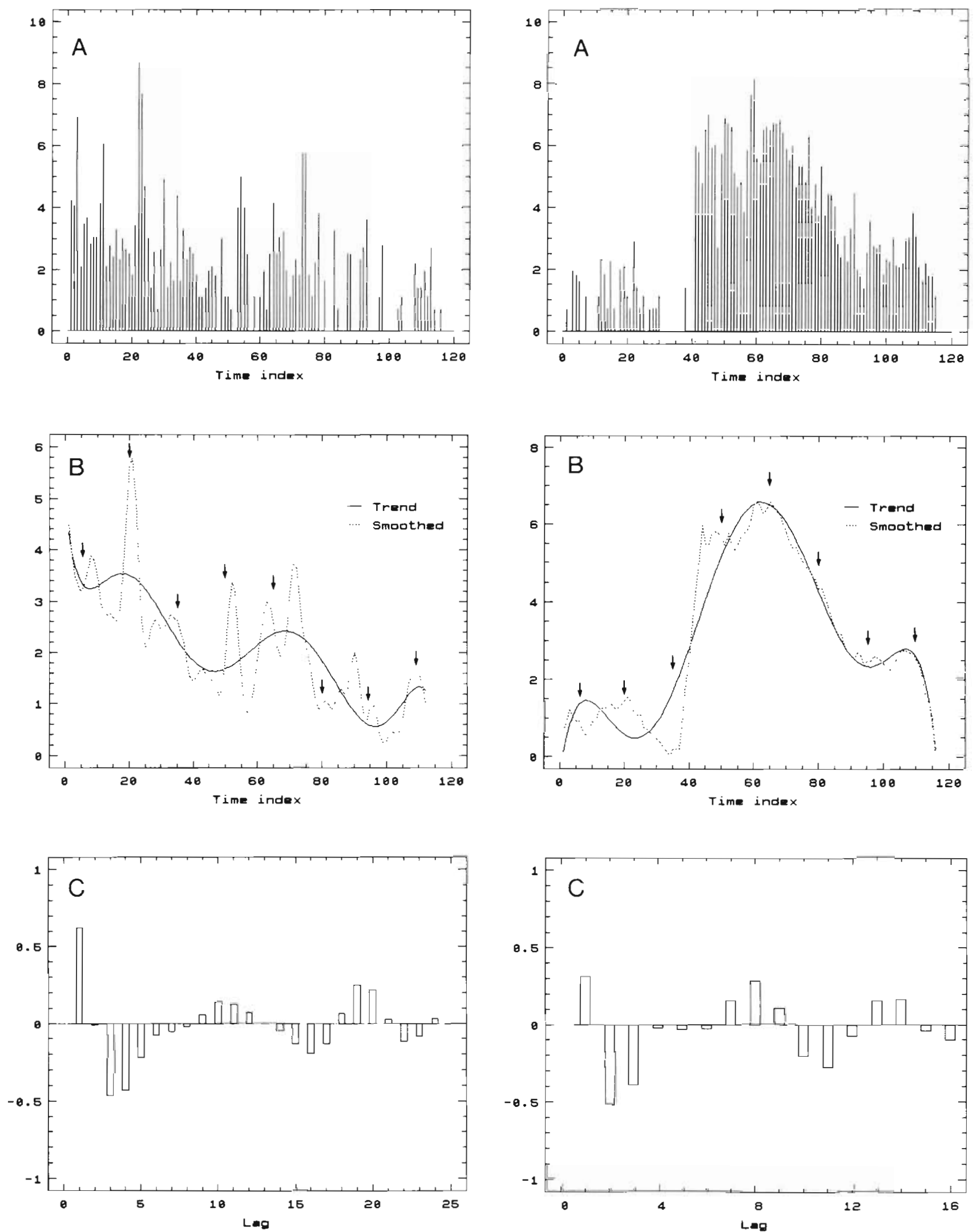

Fig. 8. As in Fig. 6 but for Macoma balthica

Fig. 9. As in Fig. 6 but for Hydrobia ulvae 
Table 2. Multiple regression of wind data on short-term changes in abundance of drifting molluscs. Variables: wind direction (di) or velocity (ve) during daytime (D) or nocturnal (N) flood (F) or ebb tides $(E)$; $A=$ daily average. Regression coefficient $\left(R^{2}\right)$ corrected for df; MSS, RSS, and TSS are model, residual, and total sum of squares, respectively, $\beta=$ coefficient of the selected variables

\begin{tabular}{|c|c|c|c|c|c|c|c|c|c|c|}
\hline \multirow[t]{2}{*}{ Species } & \multicolumn{6}{|c|}{ Selected model } & \multicolumn{4}{|c|}{ Selected variables } \\
\hline & $\mathrm{R}^{2}$ & MSS & RSS & TSS & F-ratio & $\mathrm{p}$ & Variables & $\beta$ & t-ratio & $\mathrm{p}$ \\
\hline Cerastoderma edule & 0.055 & 1.601 & 23.618 & 25.219 & 3.864 & 0.0238 & $\begin{array}{l}\text { DFdi } \\
\text { DFve }\end{array}$ & $\begin{array}{l}+0.00102 \\
-0.01865\end{array}$ & $\begin{array}{l}+2.4575 \\
-2.7678\end{array}$ & $\begin{array}{l}0.0168 \\
0.0066\end{array}$ \\
\hline Macoma balthica & 0.301 & 64.87 & 134.36 & 199.24 & 10.7185 & $<0.0001$ & $\begin{array}{l}\text { DFve } \\
\text { NFve } \\
\text { Adi } \\
\text { Eve } \\
\text { Ave }\end{array}$ & $\begin{array}{l}-0.16551 \\
-0.23295 \\
+0.00683 \\
-0.29796 \\
+0.57119\end{array}$ & $\begin{array}{l}-2.8093 \\
-3.7698 \\
+6.3885 \\
-2.4296 \\
+2.6120\end{array}$ & $\begin{array}{r}0.0059 \\
0.0003 \\
<0.0001 \\
0.0167 \\
0.0102\end{array}$ \\
\hline Ensis directus & 0.098 & 5.011 & 45.99 & 51.003 & 3.0509 & 0.0199 & $\begin{array}{l}\text { DAve } \\
\text { Fdi } \\
\text { Edi } \\
\text { Eve }\end{array}$ & $\begin{array}{l}-0.05826 \\
+0.00288 \\
-0.00271 \\
+0.05770\end{array}$ & $\begin{array}{l}-2.4290 \\
+2.5684 \\
-2.2753 \\
+2.3125\end{array}$ & $\begin{array}{l}0.0167 \\
0.0115 \\
0.0248 \\
0.0226\end{array}$ \\
\hline Hydrobia ulvae & 0.226 & 11.427 & 36.198 & 47.625 & 8.8392 & 0.0005 & $\begin{array}{l}\text { DEdi } \\
\text { NAve }\end{array}$ & $\begin{array}{l}+0.00407 \\
-0.06710\end{array}$ & $\begin{array}{l}+4.2031 \\
-3.8718\end{array}$ & $\begin{array}{l}0.0001 \\
0.0003\end{array}$ \\
\hline
\end{tabular}

Because of the topography of the studied area and the distribution of mud snails within that area, floating Hydrobia ulvae reached the trap site mainly with ebbing waters. Since this species is more active during daylight, a correlation between floater abundance and wind direction during daytime ebb tide was expected. However, there was also a significant negative correlation of floater abundance and wind velocity during night. It is still unknown if this is an artifact of the attempt to exclude the diurnal activity rhythm in this species, or an indication of stronger susceptibility to exogenous factors during the less preferred periods of the day. The latter hypothesis might also explain the corresponding occurrence of daytime-related wind factors among the nocturnally drifting bivalves in the multiple regression model.

\section{DISCUSSION}

\section{Seasonal abundance of drifting molluscs}

Benthic molluscs swimming or drifting in the water column have been observed throughout the year (Williams \& Porter 1971, Heiber 1988). However, since these studies did not recognize short-term rhythms of migratory activity, the results may be severely biased with respect to the quantitative abundance of drifters. In the present study, abundance of the bivalve species decreased or increased by 1 to 2 orders of magnitude within a few days. This is almost the same range of variation as observed seasonally by Williams \& Porter $(1971)$.
In Macoma balthica, Reukema \& de Vlas (1989) observed high abundance of drifting organisms in winter and early spring. The floating capacity of this species in cold water was experimentally tested by Sorlin (1988). However, using the same experimental design in both December and January, floating behaviour could only be stimulated in January. In the present study the number of floating juveniles strongly decreased towards October. Floating in $M$. balthica is possibly restricted to 2 separate periods of the year. The summer migrations seem to result in a rather even distribution of the young specimens over the tidal flats and may thus compensate for local losses of spat (own unpubl. data). The winter migrations are stimulated by low temperature (Sörlin 1988) and may therefore lead these freezing-sensitive (Ibing \& Theede 1975) specimens out of the upper intertidal sites towards the warmer subtidal waters.

The byssus system of cockle Cerastoderma edule spat has only recently been studied (Yankson 1986). Nevertheless, Baggermann suggested as early as 1953 that juveniles of this species have a prolonged pelagic dispersal phase. From Heiber (1988) and Fig. 6 it seems that the occurrence of postlarval cockles in the water column is restricted to summer (from June to the end of September). Observations of larger cockles in other periods of the year all seem to be due to passive displacement by strong currents or wave action (Heiber 1988 and references therein).

Ensis directus may either swim actively or use byssus threads for drifting. Seasonal abundance showed at least 2 peaks, which were attributed to several reproductive events (Fig. 7). The same seasonal abundance 
pattern was abserved by Heiber (1988). The size distribution of the (presumably thread-drifting) juveniles in the Wadden Sea (this study and Heiber 1988) indicates that byssus drifting ceases after a few weeks. It is unknown if there is a time gap between the thread drift of small spat and active swimming of larger specimens, as seems to be the case in Macoma balthica.

Floating mud snails Hydrobia ulvae have been observed throughout the year (Little \& Nix 1976, Heiber 1988), but high abundance only occurs in summer (July to October: Heiber 1988; end of July to October:present study). Generally all age classes are able to float (Newell 1962) but high abundance of floating mud snails in summer was consistently caused by 0 -group individuals $<2 \mathrm{~mm}$ high (Fig. 3 and Heiber 1988). Floating may thus explain the wider distributional ranges of juveniles as compared to adults (Smidt 1951).

\section{Short-term rhythms}

The existence of circatidal or circadian rhythms (or both; Reid \& Naylor 1989) among intertidal organisms is well known (Segal 1970, Saunders 1977, Brady 1979). In the present context, floating per se depends on tidal water movements. Therefore, the existence of circatidal rhythms cannot be derived from field studies. Likewise it is an open question whether the observed circadian rhythms reflect endogenous oscillators or are caused by exogenous factors such as light or temperature. The latter alternative may be true for mud snails. Newell (1962) observed a significant correlation between floater abundance and light intensity (i.e. changes of light intensity) in laboratory experiments.

Lunar or semilunar rhythms are also well known for intertidal organisms (Enright 1975, Saunders 1977). The $14 \mathrm{~d}$ periodicity in Ensis directus and the $15 \mathrm{~d}$ rhythm in Cerastoderma edule both closely match with the lunar cycle (Figs. 6B \& 7B). Minor deviations of the observed peaks of drifting organisms in the field and the lunar timing are regarded as indicators for the existence of endogenous clocks (Saunders 1977). Macoma balthica may be a special case of a lunar rhythm brought about by a $10 \mathrm{~d}$ endogenous oscillation. Only every third endogenous period matches with a spring tide. However, as is the case in circadian rhythms, these field observations cannot furnish proof of the existence of endogenous clocks. A semilunar cycle might also be caused by cyclic changes of sediment temperature (Vugts \& Zimmerman 1985).

The simultaneous occurrence of both circadian and lunar rhythms has been reported for several intertidal species (e.g. Segal 1970). An intensively studied exam- ple is the swimming behaviour of the sand beach isopod Eurydice pulchra. This species shows an endogenous circatidal swimming rhythm with a semilunar modulation (Jones \& Naylor 1970, Fish \& Fish 1972, Alheit \& Naylor 1976, Hastings 1981). By swimming vertically in wave-induced currents, E. pulchra may control its intertidal position (Warman et al. 1991). It is still unknown, however, if floating bivalves are able to migrate vertically in the water column. My own unpublished measurements indicate a rather regular vertical distribution of young cockles in the water column, while the vertical distribution of clams depends on individual shell length. Presumably the control of intertidal position in bivalve drifters is far less elaborate than in E. pulchra, and hydrographic factors may play a dominant role.

\section{Irregular variations}

Short-term irregular variations of the abundance of drifters in the water column from the modelled abundance curves were in part explained by wind (Table 2). Other weather-related factors may have substantially added to the explanation of residual variances (see 'Materials and methods - Statistical analyses'). But there were further weather-unrelated factors influencing the numbers of drifters caught by the nets employed. Some mollusc species may have reached the nets while creeping on drifting filamentous algae (Chaetomorpha spp., Enteromorpha spp.) which were seasonally abundant in the study area. This was the case for the polychaete Scoloplos armiger and resulted in a significant positive correlation of the numbers of S. armiger and algal volume caught. However, no such correlation with algal volume occurred in mollusc species, and therefore it is concluded that this means of migration is less important for the species studied here. Another kind of variation, apparently on a small spatial scale, was also observed. During a previous study, 2 nets of the same dimensions and construction type were mounted on a common frame to test the reliability of the numbers of drifters caught by the nets. In $>95 \%$ of all cases, the numbers per species trapped by the 2 nets did not significantly differ $\left(\chi^{2}\right.$-test, $\left.p>0.1\right)$. But in a few cases, one of the nets trapped significantly (up to 10 times) more individuals than the other. These differences were always restricted to a single species, whereas at the same time the numbers of other species were very similar between nets. Thus, some patchiness in the distribution of drifting molluscs in the water column seems to occur on a scale of tens of $\mathrm{cm}$. Presumably, the specimens do not always migrate as individuals but may form dense aggregates, for reasons which are still unknown. 
Acknowledgements. Thanks are due to A. Diederichs, J. Hanke, I. Mackensen, U. Möhle, and S. Zacker, who assisted with changing nets during low tide and evaluating the drift fauna caught. $M$. Hellwig-Armonies and $K$. Reise provided valuable comments throughout the study. An excellent set of wind data was provided by the Deutscher Wetterdienst, Wetterstation List. This study was funded by the Federal Ministry of Research and Technology.

\section{LITERATURE CITED}

Alheit, J., Naylor, E. (1976). Behavioural basis of intertidal zonation in Eurydice pulchra Leach. J. exp. mar. Biol. Ecol. 23: $135-144$

Baggermann, B. (1953). Spatfall and transport of Cardium edule L. Archs. neerl. Zool. 10: 315-342

Beukema, J. J., de Vlas, J. (1989). Tidal-current transport of thread-drifting postlarval juveniles of the bivalve Macoma balthica from the Wadden Sea to the North Sea. Mar. Ecol. Prog. Ser. 52: 193-200

Brady, J. (1979). Biological clocks. Arnold, London

Butman, C. A. (1987). Larval settlement of soft-sediment invertebrates: the spatial scales of patterns explained by active habitat selection and the emerging role of hydrodynamical processes. Oceanogr. mar. Biol. Ann. Rev. 25: 113-165

Enright, J. T (1975). Orientation in time: endogenous clocks. In. Kiñne, O. (ed.) Marane ecologyy, Vôl. II, Phÿsiological mechanisms. Wiley, London, p. 917-944

Fahrmeir, L., Kaufmann, H., Kredler, C. (1984). Regressionsanalyse. In: Fahrmeir, L., Hamerle, A. (eds.) Multivariate statistische Verfahren. de Gruyter, Berlin, p. 83-153

Fish, J. D., Fish, S. (1972). The swimming rhythm of Eurydice pulchra Leach and a possible explanation of intertidal migration. J. exp. mar. Biol. Ecol. 8: 195-200

Günther, C.-P. (1991). Settlement of Macoma balthica on an intertidal sandflat in the Wadden Sea. Mar. Ecol. Prog. Ser. 76: $73-79$

Hartung, J. (1989). Statistik. Oldenbourg, München

Hastings, M. H. (1981). Semi-lunar variations of endogenous circa-tidal rhythms of activity and respiration in the isopod Eurydice pulchra. Mar Ecol. Prog. Ser. 4: 85-90

Heiber, W. (1988). Die Faunengemeinschaft einer großen Stromrinne des Wurster Wattengebietes (Deutsche Bucht). Ph.D. thesis. Univ. of Bonn

This article was submitted to the editor
Ibing, J., Theede, H. (1975). About freezing resistance of littoral molluses from the German coast of the North Sea. Kieler Meeresforsch. 31: 44-49

Jones, D. A., Naylor, E. (1970). The swimming rhythm of the sand beach isopod Eurydice pulchra. J. exp. mar. Biol. Ecol. 4: 188-199

Little, C., Nix, W. (1976). The burrowing and floating behaviour of the gastropod Hydrobia ulvae. Estuar. coast. mar. Sci. 4: 537-544

Newell, R. (1962). Behavioural aspects of the ecology of Peringia (= Hydrobia) ulvae (Pennant) (Gastropoda, Prosobranchia). Proc. zool. Soc. London 138: 49-75

Reid, D. G., Naylor, E. (1989). Are there separate circatidal and circadian clocks in the shore crab Carcinus maenas? Mar. Ecol. Prog. Ser. 52: 1-6

Reise, K. (1985). Tidal flat ecology. Springer, Berlin

Sachs, L. (1984). Angewandte Statistik. Springer, Berlin

Saunders, D. S. (1977). An introduction to biological rhythms. Blackie, Glasgow

Segal, E. (1970). Invertebrates. In: Kinne, O. (ed.) Marine ecology, Vol. I, Environmental factors. Wiley, London, p. 159-211

Sigurdsson, J. B., Titman, C. W., Davies, P. A. (1976). The dispersal of young post-larval bivalve molluscs by byssus threads. Nature, Lond. 262: 386-387

Smidt, E. L. B. (1951). Animal production in the Danish Waddensea. Meddr Kommn Danm. Fisk-og Havunders. (Ser Fiskori) 11: 1 151

Sörlin, T. (1988). Floating behaviour of the tellinid bivalve Macoma balthica (L.). Oecologia 77: 273-277

Vlas, F. de (1973). Migratie via getijstromen van jonge nonnetjes, Macoma balthica L., op en rond het Balgzand. Int. Verlag NIOZ, Texel, 1973-14, p. 1-30

Vugts, H. F., Zimmerman, J. T. F. (1985). The heat balance of a tidal flat area. Neth. J. Sea Res. 19: 1-14

Warman, C. G., O'Hare, T J., Naylor, E. (1991). Vertical. swimming in wave-induced currents as a control mechanism of intertidal migration by a sand beach isopod. Mar. Biol. 111: 49-54

Williams, A. B., Porter, H. J. (1971). A ten-year study of meroplankton in North Carolina estuaries: occurrence of postmetamorphal bivalves. Chesapeake Sci. 12: 26-32

Yankson, K. (1986). Observations on byssus systems in the spat of Cerastoderma glaucum and C. edule. J. mar biol. Ass. U.K. 66: 277-292

Manuscript first received: February 20, 1992

Revised version accepted: May 13, 1992 